\section{The hidden costs of self- management services in the accounting activity of a company}

Gary COKINS,

The founder of Analytics-Based Performance

Management LLC,

SAS Institute Inc., Cary, North Carolina, USA

Sorinel CĂPUŞNEANU,

"Dimitrie Cantemir" Christian University,

Bucharest, Romania

Dan Ioan TOPOR,

1 Decembrie 1918, Alba-Iulia, Romania,

E-mail:Dan.Topor@yahoo.com

Oana Raluca Ivan, 1 Decembrie 1918, Alba-Iulia, Romania

\section{Alostract}

This article addresses relevant aspects regarding the hidden costs of self-management services in the accounting area, within the accounting department of a company. With this aim, the authors conducted a study using a questionnaire, whose results were analyzed and interpreted. The hidden costs of the self-management of business accounting services observed in the accounting department of the company have been assessed and the causes of their generating sources were identified and analyzed. The debate of these hidden costs involved the treating of notions that exist in the accounting language, but are still not sufficiently explored by the specialists in the area. We also presented and analyzed the causes of the hidden costs of self-management in the accounting activity, as well as a reporting document for failures, arising from the case study. The article ends with the authors' conclusions regarding the hidden costs of self-management services in the accounting area.

Keywords: Hidden costs, financial reporting, company, owners, managerial accounting, management

JEL Classification: M41

\section{To cite this article:}

Cokins, G., Căpuşneanu, S., Topor, D.I. and Ivan, O.R. (2017), The hidden costs of self-management services in the accounting activity of a company, Audit Financiar, vol. XV, no. 2(146)/2017, pp. 244-253, DOI: 10.20869/AUDITF/2017/146/244

To link to this article:

http://dx.doi.org/10.20869/AUDITF/2016/144/244

Received: 15 July 2016

Revised: 13 December 2016

Accepted: 21 December 2016 


\section{Introduction}

From the beginning we will say that the theme of this approach is valid both for public entities and economic ones, addressing conceptual units that can be found to a certain extent in each type of activity. In addition to the relevance of some aspects, we will use practice or interest in the profitability of a business, but the results will be equally important for a public entity, where the budget and budget implementation are significant.

The success of a profitable and lasting business, but also of a public activity largely depends on its management, who must assume the primary responsibility to propel the entity into the orbit of the specific market segments that will guarantee an important place among the top rated companies on the market, or the most popular public entities who have duties. The management team selected by strict criteria must prove notable experiences and demonstrate the viability of its decisions, whether short term or long term decisions. It often happens that the management of a company fails to deal with unusual situations arising from the company's money management, due to weak or inadequate accounting practices. More specifically, the information provided by accounting is typically not accurate or incompletely measured and reported, and this contributes to the failure of subsequent decisionmaking. Most small companies, but also some larger companies prefer to practice "house accounting" and use their own staff to perform accounting tasks. This is because the owners fear for their data privacy and security. As a result, they try to hold control over the information provided. Some entities practice this approach since they do not have sufficient financial resources to hire external accounting services, or they do not trust the services provided by third parties. Whichever option is chosen by the management, regardless if the accountants are more or less experienced, the corporate finances cannot be left to chance. All the issues mentioned are a result of the hidden costs, whose causes will be discussed in this article. Our main objective is to highlight the hidden costs of self-management services related to the accounting activity in the accounting department of a company.

\section{Literature review}

The literature brings to the fore a number of studies on hidden costs, the most significant of them testing the hidden cost-performance method and the development proposal which belong to Professor Savall H. (Savall and Zardet, 1992). Any cost element that lacks one of the three fundamental properties (it has a known label which is accurate and normal; it is measured accurately based on known rules; it is monitored in order to verify progress based on a fixed lens) can be called hidden cost (Savall and Zardet, 1991). Choosing objectives that will determine the costs focuses on what is visible and tangible, such as: production, means of exploitation or responsibility centers. Later, this definition is extended by a more consistent formulation, according to which the hidden costs are costs that do not appear explicitly in the information system of a company, such as in the budget, in the financial accounting or management accounting, or in the journal or other document summary (Savall and Zardet, 2008). Hidden costs do not allow a quantification of results and deviations, but may allow an analysis of their causes at the root assembly, as a phenomenon closely linked to the high performance of an entity (Briciu and Căpuşneanu, 2011).

Based on this definition, the literature provides other approaches of the concept of hidden costs, which will be reviewed in terms of their identification through the accounting information systems, as well as in terms of the factors that lead to the onset or at the level of entity. Thus, some authors believe that the hidden costs are generated by official formal procedures employed outside the company and achieve a considerable level (lonaşcu et al., 2003). Hidden costs present two categories: the hidden costs that are included in visible costs and the potential hidden costs represented by the presence of internal malfunctions, such as the existence of virtual costs of corresponding subtasks (Ionaşcu et al., 2003). The causes of these potential costs can be external in nature, such as: the malfunction of public services, strikes, failure of the judiciary 
institutions to resolve disputes in a considerable period of time or solutions that could not be provided etc. Other authors think that there are other costs, expressing interests of the managers or administrators such as: the waiting interval between two batches, inadequate design, poor quality, absenteeism from work unit and others (lacob et al., 2007), as well as large buffer stocks that consume valuable resources and generate hidden costs (Salawati et al., 2012). The identification and monitoring of hidden costs is very important because they have a direct impact on the performance of a company (Albu and Albu, 2003).

General failures are caused by certain anomalies, perturbations or deviations between the ideal functioning and the actual operation of the company, whereas following elements can be identified: absenteeism, staff turnover, accidents at work, quality defects and the direct loss of productivity (Savall and Zardet, 1991). The emergence of these elements leads to the emergence of hidden costs related to: time management, working conditions, the application of strategies, integrated training and internal communication or the coordination of various activities. The organizations' socio-economic theory is focusing on the high performance of the company or the productive capacity of entities to manage their material, physical, monetary and human resources. Correcting these failures is the monetary aspect and involves hidden costs: loss due to lower operating level, extra personnel compensation, additional external services, decrease of product quality etc. All these disturbances lead to a consumption of financial or human resources, as follows: the decrease of the product quality leads to the redesign of the products, which requires additional staff or, as in the case of absenteeism, the waiting times between batches generate financial losses (lacob et al., 2007).

In the managerial accounting, we can identify following hidden costs: opportunity costs (costs of lost opportunities, costs of lost profits), environmental costs (Betianu, 2007), quality costs (Giakatis et al., 2000), subactivity costs (Taicu and Roman, 2009) etc.

\section{Methodology of research}

\subsection{Research questions}

The purpose of this article consists in the authors' attempt to identify some hidden costs of selfmanagement services in the business accounting activity, from the accounting department of some Romanian economic companies. In this sense, we tried to find answers to a series of questions as follows:

1. Is it possible to identify the hidden costs of the self-management accounting activity in the accounting department?

2. Where are the hidden costs of the selfmanagement accounting activity within your department?

3. Can you identify the root causes of the hidden costs of the self-management accounting activity?

4. Can you control the hidden costs of the selfmanagement accounting activity?

\subsection{Instrumentation}

The design of our research focuses on the theoretical approach of the implications arising from development problems described by the questions launched at the beginning of the study. For the relevance of the study we used, as instruments, the induction, the deduction and the questionnaire, which addressed specialists in accounting, classified in two groups (heads of department and accountants).

\subsection{Sample and data analysis}

The study sample included 1424 persons, belonging to the categories mentioned above. After collecting the questionnaires and centralizing the data, we arrived at the following structure of the responses (Table no. 1).

As it can be seen, the largest share of the two categories of specialists surveyed suggests identifying, analyzing and combating hidden costs. Given this situation, our study results continued empirically with the identification, analysis and presentation of preventive measures, which are described below. The graphic representation of the responses is presented in Figure 1. 


\begin{tabular}{|c|c|c|c|c|}
\hline \multirow{3}{*}{ Questions } & \multicolumn{4}{|c|}{ Respondents categories } \\
\hline & \multicolumn{2}{|c|}{ Heads of department } & \multicolumn{2}{|c|}{ Accountants } \\
\hline & Yes (\%) & No $(\%)$ & Yes (\%) & No (\%) \\
\hline $\begin{array}{l}\text { 1. Is it possible to identify the hidden costs of the self- } \\
\text { management accounting activity in the accounting } \\
\text { department? }\end{array}$ & 87.57 & 2.43 & 86.29 & 13.71 \\
\hline $\begin{array}{l}\text { 2. The hidden costs of the self-management accounting } \\
\text { activity within your department come from: }\end{array}$ & 50.31 & 49.69 & 65.78 & 34.22 \\
\hline $\begin{array}{l}\text { 2.1. Reporting inaccurate information to management } \\
\text { 2.2. The occurrence of errors in the calculation of salaries }\end{array}$ & 7.45 & 5.59 & 20.50 & 9.53 \\
\hline and other accounting documents & 9.00 & 7.76 & 24.33 & 8.63 \\
\hline 2.3. Inadequacy in meeting deadlines & 22.68 & 18.64 & 10.34 & 7.62 \\
\hline 2.4. Using inexperienced accountants & 10.24 & 16.15 & 10.16 & 7.08 \\
\hline 2.5. Other causes & 0.94 & 1.55 & 0.45 & 1.36 \\
\hline $\begin{array}{l}\text { 3. Can you identify the root causes of the hidden costs of the } \\
\text { self-management accounting activity? }\end{array}$ & 54.03 & 45.97 & 81.30 & 18.70 \\
\hline $\begin{array}{l}\text { 4. Can you control the hidden costs of the self-management } \\
\text { accounting activity? }\end{array}$ & 54.65 & 45.35 & 77.49 & 22.51 \\
\hline
\end{tabular}

Source: Authors' calculation

\section{Figure no. 1. Situation of positive responses obtained on two categories of specialists}

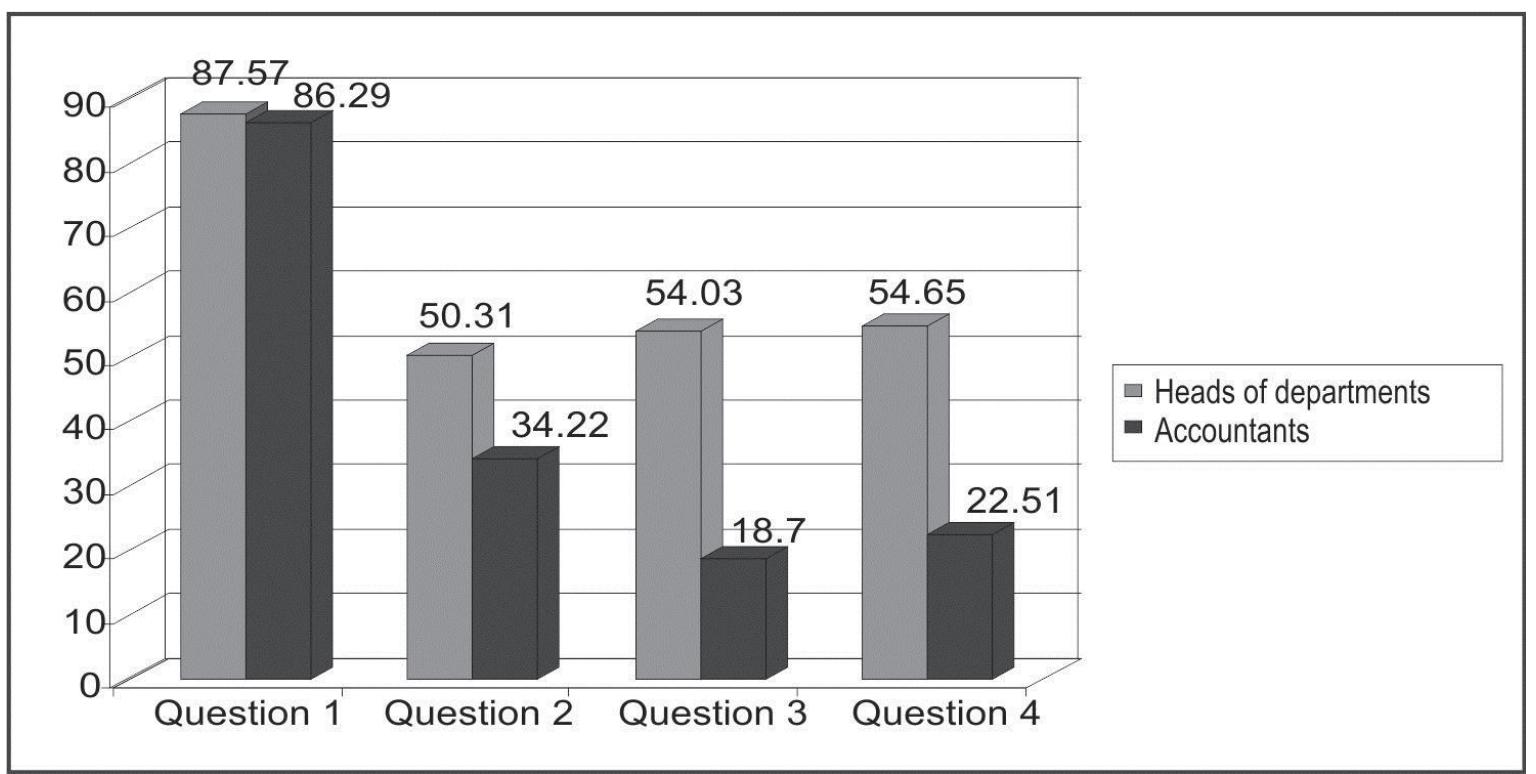

Source: Authors' representation

No. 2(146)/2017 


\section{The identification of the hidden costs of self-management services in the accounting activity of a comnany}

Based on the findings of the response analysis, we tried to explain the hidden costs of the self-management accounting activities identified in the accounting department, as follows:

\subsection{Inaccurate reporting of information to management}

Accounting data flow tracking should become the priority number one for each manager. Accountants' duties should be well separated from those of the managers, but the full responsibility for the correctness and accuracy of accounting data returns to the accountant. All accounting operations must be properly recorded in the accounting records and tracked monthly by the accounting officer and the manager. The goal is to eliminate possible errors of registration or the ambiguity of the reported accounting information. The inaccuracy of the provided data can lead to the misinterpretation of results and issues that may affect the company's image and reputation. Based on accurate and well tested information, accountants can submit the information to managers. The information should then result in better decisions for the short or long term business finances.

\subsection{The occurrence of errors in the calculation of salaries and other accounting documents}

All economic entities, regardless of their size, should have an accountant or a very well organized accounting department, in order to avoid mistakes in the calculation of the employees' salaries. The accuracy and timeliness of calculating salaries depend on many aspects that can disrupt the smooth conduct of internal activities. Employees who do not receive their salaries timely and correctly will not be sufficiently motivated to do their jobs effectively, thus giving rise to a lower labor productivity. This affects the families that depend on them triggering other social issues that are not intended to be manifested and continued, thus affecting one of the basic principles of accounting, i.e. the going concern. Therefore, the accounting department must have an effective and well-qualified staff to meet these challenges monthly. Rewarding staff in charge of these activities can be one of the keys to the successful elimination of errors or mistakes in counting and calculating salaries, thus eliminating any dysfunction in a company.

\subsection{Maladjustment in meeting deadlines}

Running a business is a very serious work and requires much time to head to the desired direction. The activity involves making payments and receipts to and from various third parties such as suppliers, banks, state, customers etc. If the accountant is not perfectly adapted to these situations, it will block the normal activity of the company, thereby obstructing other current activities. All these situations can have serious repercussions on the company and its financial stability and corrupt the decision-making process in key situations for the entity. Thus the reporting of the data to other organisms will be affected, and the company's image will be obsolete before the occurrence of prolonged hearings processes. So can we say that it is incompetence or negligence?

\subsection{Use of inexperienced accountants}

As it is well known, many economic entities pay a lot of money to accountants who are more or less competent. Is it not better to employ well-trained accountants based on an impressive CV that can guarantee the normal course of accounting activities, giving them a good salary, than to employ accountants with less experience, paying them good wages, though they cannot ensure the normal course of the accounting activities? Do we think that we only save money? Or do we want the company to operate normally and efficiently?

\subsection{The use of accounting software updates}

These costs can be found especially after the implementation of an accounting software, when a regular accountant needs a data update, in order to write and provide information to the management. For this, most software companies do not provide free additional services, such as the regular updating of software or additional software components. These costs of the company can be translated as hidden costs, especially knowing the growing need for information of the 
companies, meant to ensure efficient decisions. In other words, the cost of implementing a software attracts mostly hidden costs as mentioned above.

\subsection{Participation in information sessions or improvement courses for accountants}

The business environment is constantly moving and adapting to all legislative requirements occurring during the activity of a public or company. All changes in the accounting and tax legislation with direct or indirect effects on the entity's activity should be considered by directly informing accountants or through their participation in information courses, training, updating or improvement. All of them include some hidden costs, due to the higher total costs incurred unexpectedly monthly or annually, that affect the final result to some extent.

\section{The evaluation of the hidden costs of the self-management accounting activity in the accounting department. Identifying the causes and sources of hidden costs}

The evaluation of hidden costs is realized as follows:

Over salaries or additional wages are caused by errors made in preparing the supporting documents (payroll, cost sheets, other documents) or staff rotation caused by changes made by function, when other responsible parties s (managers and specialists) take over duties of subordinates or colleagues. Hence, the entity is obliged to pay additional amounts for the performance of additional tasks by managers or other executive employees. The general causes are linked to changes in function due to absenteeism, the lack of staff or the lack of experience, the take-over of tasks by managers due to the overload of the subordinates etc.

Over time or additional time are generated by some additional activities that do not add value to the department. They give rise to costs because the infrastructure and the equipment working in the department are not used properly. The causes are linked to errors (errors detected due to staff negligence), unnecessary activities (unnecessary procedures), the lack of precise information (lack of organization and information), distractions (weekly information and analysis sessions), inefficiency of work equipment (use of old equipment or inefficient software) etc. The over consumption or the additional consumption of consumables is generated by those inputs that could have been avoided. The causes are linked to errors (printing errors), the use of low quality supplies (cheap) and the waste of consumables etc.

Non-value is the inaccurate reporting of key information to senior management or specialized departments with major involvement in detecting malfunctions and insufficient time for the information activities. The general causes are linked to the use of low-skilled, inexperienced personnel (know-how). A company is considered to be composed of a series of interactions between different structures and behaviors. According to our investigation, we identified the following generating factors of hidden costs in the accounting department of a company (Savall and Zardet, 2008): (1) The administrative dysfunction (work organization, communication, coordination, information processing, time management, information system errors due etc.); (2) The behavioral dysfunction (individual, group, community, pressure groups); (3) The structural dysfunction (physical, technological, organizational, demographic, mental).

For a proper calculation of the hidden costs, we opted for the formula below.

$$
\text { Hidden Costs }(\mathrm{HC})=\mathrm{OE}+\mathrm{OC}
$$

Where:

$\mathrm{OE}=$ Organizational Expenses (additional wages for overtime, additional expenses);

$\mathrm{OC}=$ Opportunity Costs (non-quality, low productivity).

\section{Greating the framework for reporting dysfunctions}

Once identified and evaluated, the hidden costs must be recovered to be translated, thus contributing to the achievement of economic performance.

The conversion of hidden costs is the process whereby once they have been identified; the attempt to recover 
them to some extent contributes to achieving economic performance.

The most important problem is to separate the general hidden costs from other hidden costs, knowing the fact that some hidden costs generate some other hidden costs (e.g., the costs of preparing accounting staff generate other costs related to the acquisition of software or updates thereof). To watch the hidden costs from the standpoint of their frequency, causes and impact on the economic performance, we can draft an overview like the one below (Table no. 2):

\section{Table no. 2.The analysis of dysfunctions in terms of the economic impact produced by the hidden costs}

\begin{tabular}{|l|c|l|l|}
\hline \multicolumn{1}{|c|}{$\begin{array}{c}\text { The name of the hidden } \\
\text { cost }\end{array}$} & $\begin{array}{c}\text { Production } \\
\text { frequency }\end{array}$ & \multicolumn{1}{|c|}{ Causes } & \multicolumn{1}{|c|}{ Economic impact } \\
\hline Absenteeism & Monthly & Time management & Over salaries \\
\hline Staff rotation & Quarterly & $\begin{array}{l}\text { Integrated training Strategic } \\
\text { implementation }\end{array}$ & $\begin{array}{l}\text { Over times } \\
\text { Over consumption }\end{array}$ \\
\hline $\begin{array}{l}\text { Work accidents and } \\
\text { professional diseases }\end{array}$ & Monthly & & $\begin{array}{l}\text { Non-production } \\
\text { Non-value }\end{array}$ \\
\hline Product quality & Monthly & & $\begin{array}{l}\text { Risks } \\
\text { Work conditions } \\
\text { Wok organization }\end{array}$ \\
\hline Deviations from productivity & Monthly & & $\begin{array}{l}\text { Communication-cooperation- } \\
\text { coordination }\end{array}$ \\
\hline
\end{tabular}

Source: Authors' determination

\section{Gase study on the determination of the hidden costs of the self-management accounting activity}

The accounting department of a Romanian company prepares an annual forecasted budget that includes: income - 500,000 lei, expenses - 460,000 lei and profit $-40,000$ lei. In preparing the forecast, the accountants did not take into account the opinion of the legal service, on legal actions of some employees, which were concluded with final and irrevocable executions.
During the year, due to the failures and the actual outturn, following revenues and expenses were recorded: income -500,000 lei, expenses -520,000 lei, deficit 20,000 lei . The hidden costs amounted to 40,000 lei (non-income). Costs savings are $35 \%$ of 40,000 lei, i.e. 14,000 lei. If failures related to overspending hadn't existed, the actual or presumably visible costs would have amounted to 460,000 lei 12,000 lei $=448,000$ lei. Overspending (over salaries) $=$ $(460,000$ lei $+20,000$ lei $)-448,000$ lei $=32,000$ lei . The hidden costs amounted to 40,000 lei $+32,000$ lei $=$ 72,000 lei. After these calculations, the income statement has the following structure (Table no. 3):

\section{Table no. 3. Income statement highlighting hidden costs}

\begin{tabular}{|l|r|l|r|}
\multicolumn{1}{|c|}{ Explanations } & \multicolumn{1}{c|}{ Amount (lei) } & \multicolumn{1}{c|}{ Explanations } & \multicolumn{1}{c|}{ Amount (lei) } \\
\hline Visible expenses & 448,000 & Provided expenses & 460,000 \\
\hline Hidden cost of dysfunctions: & 72,000 & Non-value & 40,000 \\
\hline - over salaries & 32,000 & Provided income & 500,000 \\
\hline - non-value & 40,000 & Deficit (loss) & 20,000 \\
\hline Total & 520,000 & Total & 520,000 \\
\hline
\end{tabular}

Source: Romanian company's data 
From the example above, the company carried out an investment in a computer program and the situation is as

follows (Table no. 4):

\section{Table no. 4. Total cost of the potential gain creation through an investment}

\begin{tabular}{|l|r|}
\hline \multicolumn{1}{|c|}{ Explanations } & \multicolumn{1}{|c|}{ Value (lei) } \\
\hline 1. New software (computer program) & 4000 \\
\hline 2. The period of training of personnel & 6000 \\
\hline 3. Total cost of creation of the potential gain & 10000 \\
\hline
\end{tabular}

Source: Romanian company's data

The conversion of hidden costs in value-added due the creation of potential gain is performed as

follows (Table no. 5):

\begin{tabular}{|l|c|c|c|}
\hline \multicolumn{1}{|c|}{ Table no. 5. Conversion of hidden costs } \\
\hline \multicolumn{1}{|c|}{ Impact of potential gain creation } & $\begin{array}{c}\text { Annual hidden } \\
\text { costs (lei) }\end{array}$ & $\begin{array}{c}\text { Conversion rate of } \\
\text { hidden costs } \\
\text { in value-added }\end{array}$ & $\begin{array}{c}\text { Annual hidden } \\
\text { performance expected } \\
\text { (lei) }\end{array}$ \\
\hline $\begin{array}{l}\text { 1. Inaccurate reporting of information to } \\
\text { management }\end{array}$ & 2,700 & $2 / 3$ & 1,800 \\
\hline 2. Use of inexperienced accountants & 1,200 & $2 / 3$ & 800 \\
\hline $\begin{array}{l}\text { 3. Reception of responsibilities from some } \\
\text { subordinates or colleagues }\end{array}$ & 6,000 & $1 / 3$ & 2,000 \\
\hline $\begin{array}{l}\text { 4. Errors made in the preparation of supporting } \\
\text { documents }\end{array}$ & 2,000 & $3 / 3$ & 2,000 \\
\hline $\begin{array}{l}\text { 5. Staff rotation caused by changes made by } \\
\text { function }\end{array}$ & 3,600 & $2 / 3$ & 2,400 \\
\hline & 15,000 & $58.06 \%$ & 9,000 \\
\hline
\end{tabular}

Source: Romanian company's data

The graphical representation of the data is provided in Figure no. 2.

\section{Data analysis}

Based on the analyzed data we can see that the impact of the potential gain creation is reflected by: inaccurate reporting of information to management; use of inexperienced accountants; reception of responsibilities from some subordinates or colleagues; errors made in the preparation of supporting documents; staff rotation caused by changes made by function. If these managerial deficiencies had not existed, no amounts pending in court would have been provisioned and no hidden costs would have emerged. Of the total annual hidden costs of 15,500 lei only a proportion of $58.06 \%$ is recovered, and that is 9,000 lei. The situation presented can be combined and analyzed in accounting synthesis documents like the income statement (Căpuşneanu and Briciu, 2011) or the annexes of the results account and along with other synthesis situations (Cokins et al., 2011), respectively with the information needs of the management. 


\section{Figure no. 2. Reporting of the annual hidden costs and the annual hidden performance}

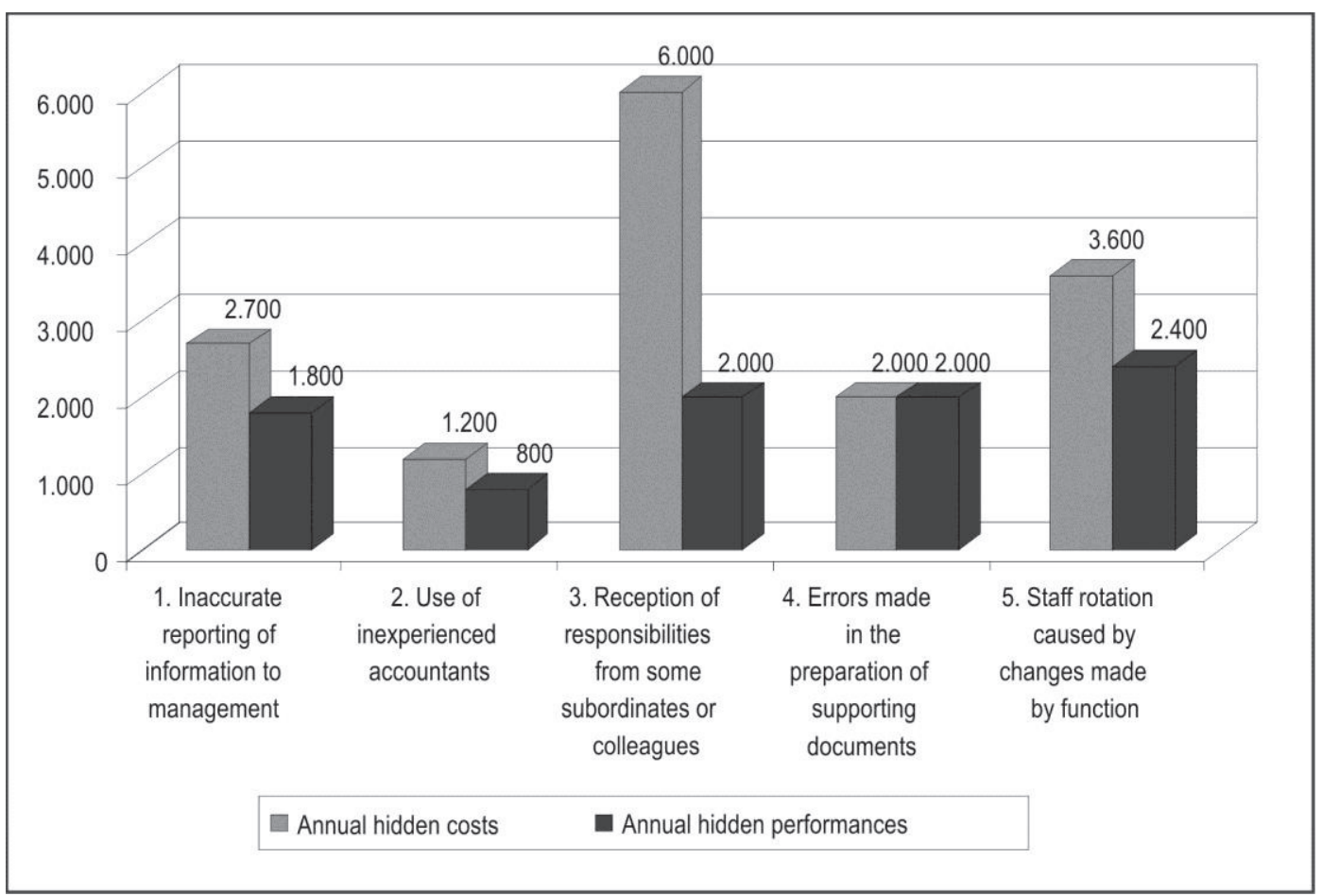

Source: Authors' representation

\section{Bonclusions}

The analysis of the hidden costs is one of the priorities of a responsible accounting department of a company, or other persons delegated with this responsibility. This task should be assigned to the director of the accounting department, who has a series of responsibilities in this respect. In this case, we plead for delegating this responsibility to a person specifically designated to analyze hidden costs. All information obtained should be processed and included in the accounting synthesis documents that will serve to support managerial decisions. The impact the of hidden costs on the performance of a company should be reviewed internally to identify their causes. Although at first glance it seems to be a complex activity, in time it will become a routine that will lead to the rapid identification of malfunctions that can eliminate them. Their conversion will bring value-added and will contribute to reducing the losses of the company.

\section{REFERENCES}

1. Albu, N. and Albu, C., (2003), Instrumente de management al performantei [Instruments of managing the performance], vol. I, Editura Economică, Bucharest.

2. Betianu, L. (2007), Environmental cost accounting, The Annals of the University of Oradea, Economic Sciences, Tom XVI, Volume II. Section: Finance, Accounting and Banks, pp. 125-128.
3. Briciu, S. and Căpuşneanu, S., (2011), The increase of performance of an entity by the conversion of the hidden costs, Annales Universitatis Apulensis Series Oeconomica, vol. 13, no. 2, pp. 207-214.

4. Căpuşneanu, S. and Briciu, S., (2011), Control and analysis of costs based on results account of the ABC mehod, International Journal of Academic Research in Business and Social Sciences, vol. 1, no. 3, pp. 146-147. 
5. Cokins, G., Căpuşneanu, S. and Barbu, C.M. (2011), Decisions based on synthesis documents information of the ABC (Activity-Based Costing) method, International Journal of Accounting and Financial Reporting, vol. 1, no. 1, pp. 119-125.

6. Giakatis, G., Enkawa, T. and Washitani, K. (2000), Quality Costs and Hidden Quality Costs: Their Importance and Their Environmental Association, APDSI, Full Paper, [Online], disponibil la http://gebrc.nccu.edu.tw/proceedings/ APDSI/2000/list/pdf/P-031.PDF, accesat pe data de 3 martie 2016.

7. Ionaşcu, I., Filip, A.T. and Stere, M. (2003), Control de gestiune [Management control], Editura Economică, Bucureşti.

8. lacob, C., lonescu, I. and Goagara, D. (2007), Management accounting in line with international practice, Editura Universitaria, Craiova.
9. Salawati, S., Tinggi, M. and Kadri, N. (2012), Inventory management in Malaysian construction firms: impact on performance, SIU Journal Management, vol. 2, no. 1, pp. 59-60.

10. Savall, H. and Zardet, V. (1991), Maîtriser les coûts et les performances cachés, Economica, Paris.

11. Savall, H. and Zardet, V. (1992), Le noveau controle gestion. Méthode des côuts-pérformance cáches [New management control: The hidden cost-performance method], Eyrolles, Paris.

12. Savall, H. and Zardet, V. (2008), Mastering hidden costs and socio-economic performance, Charlotte, USA: Information Age Publishing, pp. 8-14.

13. Taicu, M. and Roman, A. (2009), The importance of knowing the enterprise's hidden costs, The Annals of the University of Oradea, Economic Sciences, Volume III. Section: Finance, Accounting and Banks, pp. 1192-1196. 